\title{
INTENSI GENERASI MILENIAL DALAM MEMILIH PEMBIAYAAN KREDIT KEPEMILIKAN RUMAH PADA BANK SYARIAH DI INDONESIA
}

\section{Sheila Annisa, Nurdin Sobari dan Hardius Usman}

Universitas Indonesia

E-mail: sheila.annisa@ui.ac.id,nurdin.sobari@ui.ac.id,dan hardius@stis.ac.id

\section{Diterima:}

14 Juni 2021

Direvisi:

08 Juli 2021

Disetujui:

15 Agustus 2021

\section{Abstrak}

Memiliki rumah adalah idaman setiap orang, karena tempat tinggal merupakan kebutuhan dasar manusia. Pada kenyataannya, kemampuan finansial atau tingkat daya beli tidak sejalan dengan kenaikan harga perumahan yang cenderung naik setiap tahunnya. Peluang inilah yang dimanfaatkan oleh banyak lembaga keuangan termasuk perbankan syariah untuk menawarkan produk pembiayaan dalam hal kepemilikan rumah (KPR). Masyarakat usia produktif merupakan prospek bagi pertumbuhan bank syariah. Penelitian ini bertujuan untuk mengetahui faktor - faktor yang dapat memengaruhi intensi generasi milenial dalam memilih pembiayaan KPR di bank Syariah. Penelitian ini mengangkat Theory Reasoned Action dengan menggunakan populasi responden yang berasal dari nasabah bank generasi milenial di Indonesia. Variabel dependen dalam penelitian ini adalah atitude dan intensi generasi milenial, sedangkan variabel independen yang digunakan dalam penelitian ini adalah Service Quality, Product Choice, Islamic Debt Policy, Pricing Policy, Institutional Compliance on Maqashid dan Social Influence. Data dikumpulkan menggunakan kuesioner dengan skala likert. Sedangkan untuk mengetahui karakteristik responden dan untuk memenuhi tujan penelitian, data dianalisis dengan menggunakan Partial Least Square (PLS) dengan bantuan aplikasi SMART PLS. Dari hasil penelitian didapatkan bahwa ada tiga variabel independen yang berpengaruh positif dan signifikan terhadap terbentuknya Attitude seseorang, yaitu Product Choice, Institutional Compliance on Maqashid dan Social Influence. Selain itu, Attitude sendiri memengaruhi sebesar $73 \%$ terhadap intensi generasi milenial dalam memilih KPR di Bank Syariah.

Kata Kunci: Kredit Kepemilikan Rumah, Theory

$$
\text { Reasoned Action, Generasi Milenial. }
$$

Abstract
Purchasing a house is everyone's dream, because a house is
place to live is a basic human need. In fact, the financial ability
or level of purchasing power is not in line with the increase in
housing prices which tend to rise every year. This opportunity is
used by many financial institutions including Islamic banks to
offer financing products in terms of home ownership (in
Indonesia's other words called KPR). The productive age
community is a prospect for the growth of Islamic banks. The


purpose of this study is to determine the factors that can influence the intention of the millennial generation in choosing mortgage financing in Islamic banks. This study raises the Theory of Reasoned Action by using a population of respondents who come from millennial generation bank customers in Indonesia. The dependent variable in this study are the attitude and intentions of the millennial generation, while the independent variables used in this study are Service Quality, Product Choice, Islamic Debt Policy, Pricing Policy, Institutional Compliance on Maqashid, and Social Influence. Data were collected using a questionnaire with a Likert scale. Meanwhile, to determine the characteristics of the respondents and to fulfil the research objectives, the data were analysed using Partial Least Square (PLS) with the help of the SMART $P L S$ application. From the results of the study, it was found that there are three independent variables that have a positive and significant effect on the formation of a person's attitude, which are Product Choice, Institutional Compliance on Maqashid, and Social Influence. In addition, Attitude itself affects 73 percent of the millennial generation's intentions in choosing mortgages in Islamic banks.

Keywords: Islamic Home Financing, Theory Reasoned Action, Millennial generation

\section{Pendahuluan}

Masyarakat usia produktif saat ini terutama generasi milenial berkontribusi cukup besar dalam menggerakan perekonomian. Dalam sebuah penelitian, generasi milenial merupakan kelompok penting yang menjadi target ritel dan perusahaan produk konsumen karena ukuran dan daya beli yang tinggi. Dengan ukuran saat ini, generasi milenial menjadi fokus studi untuk melihat efeknya terhadap aktivitas ekonomi (Christopher Kurz, Geng Li, 2018). Di Indonesia, pembelian sebuah rumah tinggal merupakan keputusan yang besar bagi individu ataupun sebuah keluarga. Indonesia diprediksi mengalami bonus demografi, yaitu jumlah penduduk usia produktif lebih besar dibandingkan dengan penduduk usia non-produktif.

Namun dibalik potensi yang besar ini, untuk mampu membeli rumah bukanlah hal yang mudah dikarenakan kenaikan pendapatan tidak seimbang dengan kenaikan harga properti setiap tahunnya. Hal ini didukung oleh studi yang dilakukan oleh (Hoolachan \& McKee, 2019) dimana tantangan ini berkaitan erat dengan pasar tenaga kerja generasi muda yang melemah, yang ditandai oleh kontrak hubungan kerja dengan gaji rendah. Lebih jauh lagi, generasi milenial sering memiliki banyak hutang dan dihadapkan dengan biaya hidup yang jauh lebih tinggi dibandingkan generasi - generasi sebelumnya pada usia yang sama (Brant, K., \& Castro, 2019). Meskipun demikian, (Dickerson, 2016) menyampaikan bahwa generasi milenial tetap memiliki keinginan untuk memiliki rumah. Generasi milenial mulai sadar bahwa kemampuan untuk membeli rumah terbatas, sehingga banyak dari mereka yang ingin membeli rumah melalui mekanisme kredit $(50,2 \%)$ dibandingkan tunai $(49,8 \%)$. Salah satu produk yang ditawarkan Bank Syariah adalah pembiayaan kepemilikan rumah (PKR).

Namun demikian, masih banyak kendala yang perlu dibenahi dari KPR syariah, misalnya terjebak dengan Islamic labelling, minimnya sosialisasi dan penyebaran informasi, dan lain - lain. Kajian terkait hal ini telah banyak dilakukan, misalnya hasil dari pada bank syariah di Malaysia, kekurangan ini bisa disebabkan berbagai macam ha 
seperti dari kualitas pelayanan, produk yang kurang variatif, kebijakan hutang yang kurang islami, mengesampingkan kepatuhan terhadap aturan syariah, sampai dengan pengaruh sosial yang berpengaruh pada sikap nasabah dalam mengambil keputusan. Hal ini didukung oleh penelitian yang dilakukan oleh (Mirza Astia Amri, 2018) yang menyatakan bahwa nasabah pada suatu bank di Sumatera Utara lebih memilih KPR konvensional dibandingkan unit syariahnya, dikarenakan alasan variasi produk, harga dan iklan. Selain itu, adapula penelitian yang dilakukan oleh (Ismail et al., 2014) terkait kriteria pemilihan KPR rumah di Malaysia. Penelitian tersebut dilakukan dengan memberikan kuisioner kepada 160 orang karyawan dalam sebuah institusi keuangan. Dengan menggunakan metode Stratified Random Sampling, hasil penelitian menunjukkan bahwa Reputation, Service Quality, Advertisement dan Social Influence merupakan faktor yang berkaitan dan dapat mempengaruhi pemilihan KPR syariah.

Penelitian terkait intensi generasi milenial dalam memilih produk KPR Bank Syariah di Indonesia masih sangat terbatas. Dari penelitian - penelitian yang dijabarkan sebelumnya, populasi responden berasal dari kelompok nasabah di satu lembaga keuangan syariah, dimana sampel responden kurang tergeneralisasi. Oleh karena itu, penelitian ini bertujuan untuk mengetahui faktor-faktor yang memengaruhi attitude nasabah yang selanjutnya berimplikasi pada intensi pembiayaan Rumah Syariah. Studi ini dilakukan dengan menggunakan pendekatan kuantitatif, penelitian ini sangat menarik untuk lebih memahami faktor-faktor tersebut untuk memastikan KPR Syariah tetap kompetitif. Dengan pemahaman tersebut, penelitian ini diharapkan: (1) Dapat mengisi celah atau kekosongan dari penelitian sebelumnya terkait intensi generasi milenial dalam hal pembiyaan KPR di Bank Syariah, (2) Berguna bagi peneliti maupun akademisi berikutnya untuk memperdalam studi ini lebih lanjut dan (3) Berguna bagi perbankan syariah dimana temuan penelitian sangat penting untuk perencanaan yang lebih baik dari penawaran maupun pemasaran KPR Syariah. Hal ini akan membantu pengelola Bank Syariah untuk merumuskan strategi yang dapat meningkatkan pangsa pasar KPR Syariah di masa depan.

\section{Metode Penelitian}

1. Populasi dan Sampel Penelitian

Objek yang menjadi populasi dari penelitian ini adalah generasi milenial di Indonesia dengan beberapa kriteria yang telah ditentukan, antara lain: lahir antara tahun 1980 - 1994, bekerja, merupakan nasabah bank responden sedang atau ada keinginan untuk membeli rumah dalam waktu kurang dari satu tahun ke depan. Jumlah sampel yang digunakan mengacu pada teori yang dikemukakan oleh (Larasati, 2019). Secara total terdapat 32 indikator pernyataan yang digunakan dalam model untuk penelitian ini, sehingga berdasarkan teori tersebut jumlah sampel minimal yang dibutuhkan adalah sebesar 32 x $5=160$ sampel. Dalam pengambilan sampel dibutuhkan teknik sampling untuk menentukan sampel mana yang akan digunakan (Sugiyono, 2012). Teknik sampling yang digunakan dalam penelitian ini adalah non-probability sampling dengan jenis purposive sampling.

\section{Data Penelitian dan Teknik Analisis Data}

Data primer dalam penelitian ini didapatkan secara langsung melalui pemberian kuesioner survei kepada sampel penelitian (responden). Kuisioner penelitian menggunakan media elektronik berupa Google Form yang disebarkan melalui email dan aplikasi media sosial seperti WhatsApp, Instagram, Telegram, Line dan lain sebagainya. Hasil pengumpulan kuisioner inilah kemudian yang dianalisis menggunakan teknik analisis data Partial Least Square (PLS). 


\section{Partial Least Square (PLS)}

Partial Least Square (PLS) merupakan teknik statistik multivariat yang biasa digunakan untuk menangani banyak variabel respon serta variabel eksplanatori. PLS merupakan suatu teknik prediktif yang dapat menangani banyak variabel independen, bahkan sekalipun terjadi multikolinearitas diantara variabel - variabel tersebut (Widjieanto, 2020).

Selain itu, (Ghozali, 2016) menyatakan bahwa PLS merupakan metode analisis yang tidak mengaharuskan data berdistribusi normal, dan ukuran sampel tidak harus besar. Beliau menyebutkan bahwa PLS dapat digunakan untuk tujuan konfirmasi, seperti pengujian hipotesis dan tujuan eksplorasi. Langkah-langkah pengujian yang akan dilakukan meliputi dua tahap, yaitu evaluasi outer model atau model pengukuran dan evaluasi terhadap inner model atau model struktural.

\section{Hasil dan Pembahasan}

\section{Profil responden dan Analisa Statistik Deskriptif}

Pemaparan profil responden bertujuan untuk mengetahui sebaran responden yang ikut serta dalam penelitian ini baik yang sesuai dengan kualifikasi yang ditentukan maupun karakteristik demografinya. Kriteria responden yang ditentukan dalam penelitian ini antara lain; nasabah merupakan kelahiran tahun 1980 - 1994, nasabah bank, dan apakah sedang memiliki fasilitas pembiayaan KPR di Bank Syariah maupun ada ketertarikan mengambil KPR di Bank Syariah dalam kurun waktu satu tahun ke depan. Dari kuisioner yang disebar, diperoleh 170 responden yang memenuhi kriteria penelitian. Data responden tersebut selanjutnya dianalisa untuk menjawab pertanyaan penelitian tentang intensi generasi milenial terhadap pembiayaan kepemilikan rumah di bank syariah. Berikut ini merupakan hasil distribusi responden berdasarkan beberapa pengelompokkan:

\begin{tabular}{|c|c|c|c|c|c|}
\hline \multicolumn{3}{|c|}{ Nasabah Bank Syariah } & \multicolumn{3}{|c|}{ Non Nasabah Bank Syariah } \\
\hline $\begin{array}{c}\text { Jenis } \\
\text { Kelamin }\end{array}$ & \multicolumn{2}{|c|}{ Domisili } & \multirow{2}{*}{ Jenis Kelamin } & \multicolumn{2}{|c|}{ Domisili } \\
\hline \multirow{2}{*}{ Pria } & Pulau Jawa & 29 & \multirow{2}{*}{ Pria } & Pulau Jawa & 38 \\
\cline { 2 - 3 } \cline { 5 - 6 } & Luar Pulau Jawa & 3 & & Luar Pulau Jawa & 3 \\
\hline \multirow{2}{*}{ Wanita } & Pulau Jawa & 26 & \multirow{2}{*}{ Wanita } & Pulau Jawa & 67 \\
\cline { 2 - 3 } \cline { 5 - 6 } & Luar Pulau Jawa & 3 & & Luar Pulau Jawa & 1 \\
\hline \multicolumn{2}{|c|}{ Jumlah } & 61 & & Jumlah & 109 \\
\hline
\end{tabular}

Gambar 1. Distribusi Jumlah responden berdasarkan gender dan domisili

Dari distribusi responden berdasarkan gender dan domisili, didapatkan distribusi responden relative seimbang yaitu sebanyak $42,9 \%$ pria dan $57,1 \%$ wanita. Sedangkan berdasarkan domisili, mayoritas responden berasal dari Pulau Jawa, sebanyak 94,1\% 


\begin{tabular}{|c|c|c|c|c|c|}
\hline \multicolumn{3}{|c|}{ Sudah Memiliki Rumah } & \multicolumn{3}{c|}{ Belum Memiliki Rumah } \\
\hline Jenis Kelamin & \multicolumn{2}{|c|}{ Domisili } & Jenis Kelamin & \multicolumn{2}{c|}{ Domisili } \\
\hline \multirow{2}{*}{ Pria } & Pulau Jawa & 21 & \multirow{2}{*}{ Pria } & Pulau Jawa & 46 \\
\cline { 2 - 3 } \cline { 5 - 6 } & Luar Pulau Jawa & 3 & & Luar Pulau Jawa & 3 \\
\hline \multirow{2}{*}{ Wanita } & Pulau Jawa & 37 & \multirow{2}{*}{ Wanita } & Pulau Jawa & 56 \\
\cline { 2 - 3 } \cline { 5 - 6 } & Luar Pulau Jawa & 2 & & Luar Pulau Jawa & 2 \\
\hline \multicolumn{3}{|c|}{ Jumlah } & 63 & \multicolumn{3}{|c|}{ Jumlah } & 107 \\
\hline
\end{tabular}

Gambar 2. Distribusi Jumlah responden berdasarkan status KPR

\begin{tabular}{|c|c|c|c|c|c|}
\hline \multicolumn{3}{|c|}{$\begin{array}{c}\text { Memiliki fasilitas Kredit Pemilikan } \\
\text { Rumah (KPR) }\end{array}$} & \multicolumn{3}{|c|}{$\begin{array}{c}\text { Tidak memiliki fasilitas Kredit Pemilikan } \\
\text { Rumah (KPR) }\end{array}$} \\
\hline $\begin{array}{c}\text { Jenis } \\
\text { Kelamin }\end{array}$ & \multicolumn{2}{|l|}{ Domisili } & Jenis Kelamin & \multicolumn{2}{|l|}{ Domisili } \\
\hline \multirow{2}{*}{ Pria } & Pulau Jawa & 13 & \multirow{2}{*}{ Pria } & Pulau Jawa & 54 \\
\hline & Luar Pulau Jawa & 2 & & Luar Pulau Jawa & 4 \\
\hline \multirow{2}{*}{ Wanita } & Pulau Jawa & 24 & \multirow{2}{*}{ Wanita } & Pulau Jawa & 69 \\
\hline & Luar Pulau Jawa & 2 & & Luar Pulau Jawa & 2 \\
\hline & Jumlah & 41 & & lah & 129 \\
\hline
\end{tabular}

Gambar 3. Distribusi Jumlah responden berdasarkan status KPR

Kemudian berdasarkan survei, didapatkan bahwa mayoritas $63 \%$ responden belum memiliki rumah pribadi. Ditambah lagi pada tabel 3 terlihat pula bahwa 75,9\% responden sedang tidak memiliki fasilitas KPR di Bank Syariah. Hal ini konsisten dengan penelitian sebelumnya dimana masih banyak generasi milenial yang belum mempunyai tempat tinggal sendiri setelah bekerja atau memiliki penghasilan sendiri.

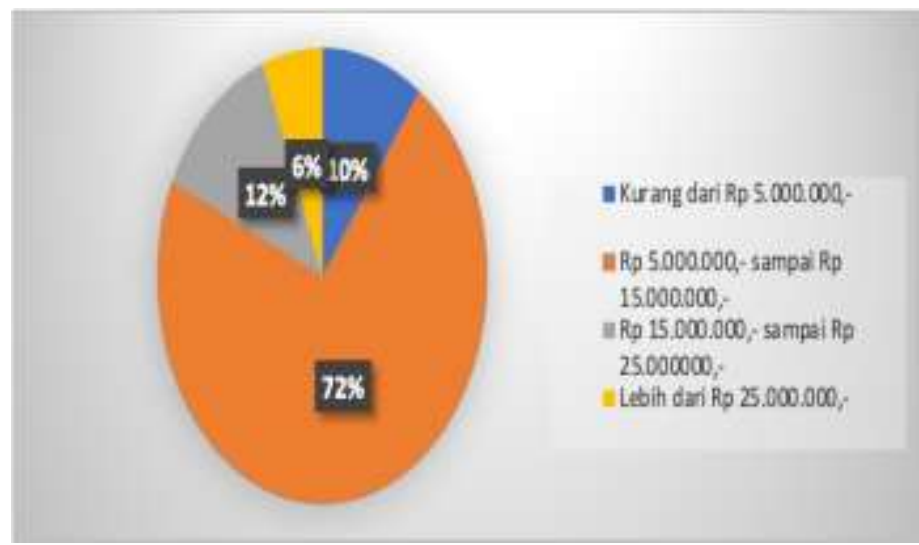

Gambar 4. Distribusi Sebaran Responden Berdasarkan Pendapatan

Jika dikaitkan dengan distribusi sebaran responden seperti pada gambar 4.1, mayoritas reponden memiliki penghasilan Rp 5.000.000 - Rp 15.000.000 per bulan nya, 
dimana hal ini diatas UMR kota Jakarta sebagai UMR tertinggi di Indonesia. Namun faktanya, responden yang memiliki penghasilan diatas UMR pun belum memiliki hunian pribadi, dengan berbagai pertimbangan.

\section{Analisa Tabulasi Silang}

Analisis tabulasi silang atau cross-tabulation adalah penggabungan distribusi frekuensi dari dua atau lebih variabel dalam satu tabel. Dengan demikian, distribusi frekuensi dari satu variabel dibagi lagi sesuai dengan nilai atau kategori dari variabel lain. Hipotesis dalam pengambilan keputusan dalam pengujian tabulasi silang dapat didasarkan pada: Nilai Chi-Square $\left(X^{2}\right)$. Membandingkan nilai chi-square hitung dengan chi-square tabel. Hipotesis nol (H0), adalah bahwa tidak ada hubungan antara variabel. Kriteria yang digunakan adalah, apabila chi-square hitung < chi-square tabel maka kesimpulan yang digunakan adalah tolak H0. Sedangkan chi-square hitung >chi-square tabel, maka dapat ditarik kesimpulan untuk terima H0. Yang artinya tidak terdapat hubungan antar variabel. Nilai probability. Apabila nilai probability lebih kecil dari tingkat signifikan 0,05 maka H0 di tolak. Sedangkan apabila probability lebih besar dari tingkat signifikan 0,05 maka H0 di terima.

Hubungan tabulasi silang yang dilakukan dikelompokkan dengan hubungan sebagai berikut:

1. Jenis kelamin dan Pendapatan Per Bulan terhadap intensi.

2. Jenis kelamin dan Domisili terhadap intensi.

3. Pendapatan Per Bulan dan Domisili terhadap intensi

\begin{tabular}{|c|c|c|c|c|}
\hline \multicolumn{5}{|c|}{ Chi-Square Tests } \\
\hline \multicolumn{2}{|c|}{ Jenis Kelamin } & Value & df & $\begin{array}{c}\text { Asymptotic } \\
\text { Significance } \\
\text { (2-sided) }\end{array}$ \\
\hline \multirow[t]{4}{*}{ Pria } & Pearson Chi-Square & $47.306^{\mathrm{b}}$ & 42 & .265 \\
\hline & Likelihood Ratio & 40.574 & 42 & .534 \\
\hline & $\begin{array}{l}\text { Linear-by-Linear } \\
\text { Association }\end{array}$ & .239 & 1 & .625 \\
\hline & $\mathrm{N}$ of Valid Cases & 73 & & \\
\hline \multirow{4}{*}{ Wanita } & Pearson Chi-Square & $39.993^{\mathrm{c}}$ & 42 & .559 \\
\hline & Likelihood Ratio & 35.131 & 42 & .764 \\
\hline & $\begin{array}{l}\text { Linear-by-Linear } \\
\text { Association }\end{array}$ & 1.816 & 1 & .178 \\
\hline & $\mathrm{N}$ of Valid Cases & 101 & & \\
\hline \multirow[t]{4}{*}{ Total } & Pearson Chi-Square & $53.162^{\mathrm{a}}$ & 42 & .116 \\
\hline & Likelihood Ratio & 53.691 & 42 & .107 \\
\hline & $\begin{array}{l}\text { Linear-by-Linear } \\
\text { Association }\end{array}$ & 1.477 & 1 & .224 \\
\hline & $\mathrm{N}$ of Valid Cases & 174 & & \\
\hline
\end{tabular}

Gambar 5. Tabulasi Silang Jenis Kelamin dan Pendapatan Per Bulan Terhadap Intensi. Sumber : Hasil Pengolahan Data menggunakan SPSS 21

Berdasarkan hasil pengujian tersebut dapat diamati bahwa nilai probability pada bagian Asymptotic Significance (2-sided) menunjukkan bahwa untuk jenis kelamin pria diperoleh nilai 0,265 (lebih besar dari pada 0,05) dan untuk jenis kelamin wanita diperoleh nilai 0,559 (lebih besar dari pada 0,05 ). Kedua hasil tersebut mengindikasikan bahwa baik pada responden pria maupun wanita HO diterima, yang bermakna bahwa 
faktor penghasilan tidak memiliki pengaruh terhadap intensi generasi milenial untuk memilih KPR di bank syariah.

\begin{tabular}{|c|c|c|c|c|}
\hline \multicolumn{5}{|c|}{ Chi-Square Tests } \\
\hline \multicolumn{2}{|c|}{ Jenis Kelamin } & Value & df & $\begin{array}{c}\text { Asymptotic } \\
\text { Significance } \\
\text { (2-sided) }\end{array}$ \\
\hline \multirow[t]{4}{*}{ Pria } & Pearson Chi-Square & $7.255^{\mathrm{b}}$ & 14 & .924 \\
\hline & Likelihood Ratio & 8.774 & 14 & .845 \\
\hline & $\begin{array}{l}\text { Linear-by-Linear } \\
\text { Association }\end{array}$ & .000 & 1 & .994 \\
\hline & $\mathrm{N}$ of Valid Cases & 73 & & \\
\hline \multirow[t]{4}{*}{ Wanita } & Pearson Chi-Square & $3.376^{\mathrm{c}}$ & 14 & .998 \\
\hline & Likelihood Ratio & 3.823 & 14 & .996 \\
\hline & $\begin{array}{l}\text { Linear-by-Linear } \\
\text { Association }\end{array}$ & .002 & 1 & .961 \\
\hline & $\mathrm{N}$ of Valid Cases & 101 & & \\
\hline \multirow[t]{4}{*}{ Total } & Pearson Chi-Square & $8.080^{\mathrm{a}}$ & 14 & .885 \\
\hline & Likelihood Ratio & 10.507 & 14 & .724 \\
\hline & $\begin{array}{l}\text { Linear-by-Linear } \\
\text { Association }\end{array}$ & .001 & 1 & .972 \\
\hline & $\mathrm{N}$ of Valid Cases & 174 & & \\
\hline
\end{tabular}

Gambar 6. Tabulasi Silang Jenis Kelamin dan Domisili Terhadap Intensi Sumber : Hasil Pengolahan Data menggunakan SPSS 21

Berdasarkan hasil pengujian tersebut dapat diamati bahwa nilai probability pada bagian Asymptotic Significance (2-sided) menunjukkan bahwa untuk jenis kelamin pria diperoleh nilai 0,924 (lebih besar dari pada 0,05 ) sedangkan nilai probability pada bagian Asymptotic Significance (2-sided) menunjukkan bahwa untuk jenis kelamin wanita diperoleh nilai 0,998 (lebih besar dari pada 0,05). Kedua hasil tersebut mengindikasikan bahwa baik pada responden pria maupun wanita H0 diterima, yang bermakna bahwa faktor domisili tidak memengaruhi intensi generasi untuk memilih KPR di Bank Syariah. 


\begin{tabular}{|c|c|c|c|c|}
\hline \multicolumn{5}{|c|}{ Chi-Square Tests } \\
\hline \multicolumn{2}{|c|}{ Berapakah rata - rata pendapatan bulanan anda? } & Value & df & $\begin{array}{c}\text { Asymptotic } \\
\text { Significance } \\
(2-\text {-sided) }\end{array}$ \\
\hline \multirow{4}{*}{$\begin{array}{l}\text { Kurang dari Rp. } \\
\text { 5.000.000,- }\end{array}$} & Pearson Chi-Square & $7.969^{\mathrm{b}}$ & 8 & .437 \\
\hline & Likelihood Ratio & 4.834 & 8 & .775 \\
\hline & $\begin{array}{l}\text { Linear-by-Linear } \\
\text { Association }\end{array}$ & 3.092 & 1 & .079 \\
\hline & $\mathrm{N}$ of Valid Cases & 17 & & \\
\hline \multirow{4}{*}{$\begin{array}{l}\text { Ro 5.000.000,- sampai } \\
\text { Rp. 15.000.000,- }\end{array}$} & Pearson Chi-Square & $7.808^{\mathrm{c}}$ & 13 & .856 \\
\hline & Likelihood Ratio & 9.454 & 13 & .738 \\
\hline & $\begin{array}{l}\text { Linear-by-Linear } \\
\text { Association }\end{array}$ & .338 & 1 & .561 \\
\hline & $\mathrm{N}$ of Valid Cases & 127 & & \\
\hline \multirow{4}{*}{$\begin{array}{l}\text { Ro 15.000.000,- sampai } \\
\text { Rp. 25.000.000,- }\end{array}$} & \begin{tabular}{|l} 
Pearson Chi-Square \\
\end{tabular} & $5.965^{\mathrm{d}}$ & 9 & .743 \\
\hline & Likelihood Ratio & 4.122 & 9 & .903 \\
\hline & $\begin{array}{l}\text { Linear-by-Linear } \\
\text { Association }\end{array}$ & .117 & 1 & .732 \\
\hline & $\mathrm{N}$ of Valid Cases & 20 & & \\
\hline \multirow{2}{*}{$\begin{array}{l}\text { Lebih dari Rp. } \\
25.000 .000,-\end{array}$} & Pearson Chi-Square & $\mathrm{e}$ & & \\
\hline & $\mathrm{N}$ of Valid Cases & 10 & & \\
\hline \multirow[t]{4}{*}{ Total } & Pearson Chi-Square & $8.080^{\mathrm{a}}$ & 14 & .885 \\
\hline & \begin{tabular}{|l|} 
Likelihood Ratio \\
\end{tabular} & 10.507 & 14 & .724 \\
\hline & $\begin{array}{l}\text { Linear-by-Linear } \\
\text { Association }\end{array}$ & .001 & 1 & .972 \\
\hline & $\mathrm{N}$ of Valid Cases & 174 & & \\
\hline
\end{tabular}

Gambar 7. Tabulasi Silang Pendapatan Per Bulan dan Domisili Terhadap Intensi Sumber : Hasil Pengolahan Data menggunakan SPSS 21

Berdasarkan hasil pengujian tersebut dapat diamati sebagai berikut :

1. Nilai probability pada bagian Asymptotic Significance (2-sided) menunjukkan bahwa untuk pendapatan per bulan kurang dari Rp.5.000.000,- diperoleh nilai 0,437 (lebih besar dari pada 0,05$)$.

2. Nilai probability pada bagian Asymptotic Significance (2-sided) menunjukkan bahwa untuk pendapatan per bulan dari Rp.5.000.000,- hingga Rp.15.000.000,- diperoleh nilai 0,856 (lebih besar dari pada 0,05 ).

3. Nilai probability pada bagian Asymptotic Significance (2-sided) menunjukkan bahwa untuk pendapatan per bulan dari Rp.15.000.000,- hingga Rp.25.000.000,- diperoleh nilai 0,743 (lebih besar dari pada 0,05 ).

Ketiga hasil pengujian tersebut mengindikasikan bahwa baik pada tingkat pendapatan dan domisili apapun $\mathrm{H} 0$ diterima, yang bermakna bahwa faktor pendapatan domisili tidak mempengaruhi intensi generasi untuk memilih KPR di Bank Syariah. 


\begin{tabular}{|c|c|c|c|}
\hline \multicolumn{4}{|c|}{ Average Variance Extracted (AVE) } \\
\hline No. & Variabel & Hasil & Kesimpulan \\
\hline 1 & Service Quality & 0.635 & Baik \\
\hline 2 & Product Choice & 0.678 & Baik \\
\hline 3 & Islamic Debt Policy & 0.698 & Baik \\
\hline 4 & Pricing Policy & 0.585 & Baik \\
\hline 5 & Institutional Compliance on Maqashid & 0.662 & Baik \\
\hline 6 & Social Influence & 0.71 & Baik \\
\hline 7 & Attitude & 0.848 & Baik \\
\hline 8 & Intensi & 0.792 & Baik \\
\hline
\end{tabular}

Gambar 9. Hasil Uji Validitas metode Convergent Validity dengan pendekatan AVE

Berdasarkan tabel diatas, hasil pengujian di atas tidak ada satupun variabel yang menghasilkan nilai AVE di bawah 0,5 yang artinya seluruh variabel ini baik dan dapat digunakan untuk penelitian. Namun karena masih ada tiga indikator yang belum memenuhi kriteria factor loadings, maka indikator tersebut dikeluarkan dari model penelitian karena tidak memenuhi persyaratan pengujian. Selain itu, dilakukan pula modifikasi pada model penelitian yang ada dengan menambahkan kemungkinan adanya hubungan langsung antara Service Quality, Product Choice, Islamic Debt Policy, Pricing Policy, Institutional Compliance on Maqashid dan Social Influence sebagai variabel independen dengan intensi sebagai variabel dependen tanpa adanya pengaruh dari attitude variabel mediasi.

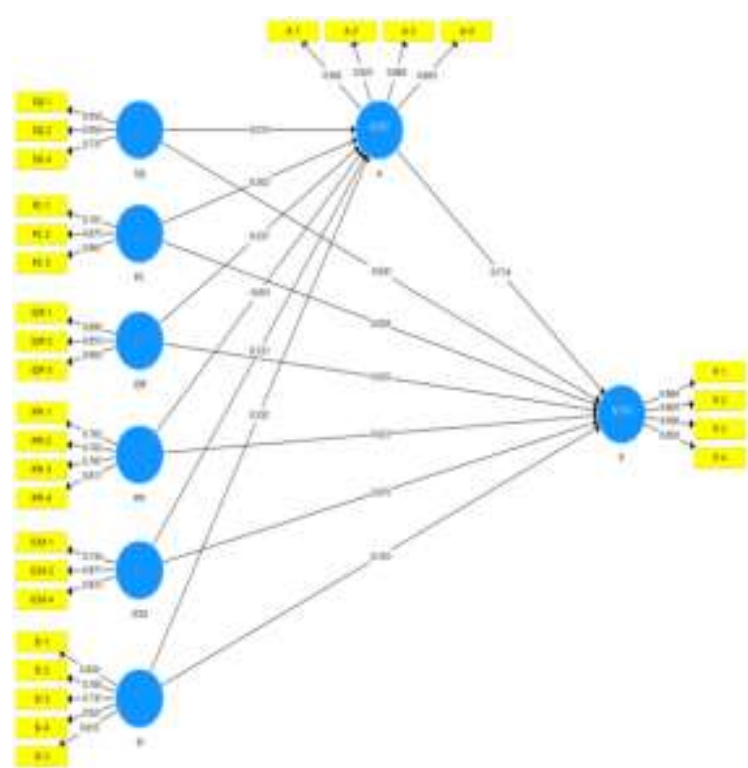

Gambar 10. Hasil Uji Algoritma PLS Modifikasi 
Dikarenakan sudah tidak ada masalah pada convergent validity, maka langkah berikutnya yang diuji adalah permasalahan yang terkait dengan discriminant validity untuk setiap konstruk dengan nilai korelasi antar konstuk dalam model (Henseler et al., 2015). Untuk mengukur hal ini, (Wong, 2019) menyebutkan terdapat dua langkah pengujian yaitu fornell larcker criterion dan/atau heterotrait-monotrait ratio of correlations (HTMT). Namun lebih menyarankan untuk menggunakan HTMT inference dibandingkan dengan fornell larcker criterion. Hal tersebut dilandaskan pada kegagalan pengujian fornell larcker criterion untuk mengidentifikasi validitas diskriminan khususnya untuk kasus-kasus besar atau model penelitian yang menggunakan variabel mediasi. Karena penelitian ini menggunakan attitude sebagai variabel mediasi, maka diutamakan HTMTinference sebagai pengujian untuk mengidentikasi Discriminant Validity.

Sebagai langkah awal untuk menjalankan pengujian $H T M T_{\text {inference, }}$ prosedur bootstrapping dengan re-sample 5000 dijalankan untuk mendapatkan nilai confidence interval (CI). Jika nilai confidence interval (CI) ditemukan kurang dari sama dengan 1.00 pada CI (2.5\%) maupun pada CI (97.5\%), hal tersebut dapat diidentifikasi bahwa tidak terdapat masalah pada discriminant validity.

\begin{tabular}{l|c|c|c|c|}
\hline & $\begin{array}{c}\text { Original } \\
\text { Sample (0) }\end{array}$ & $\begin{array}{c}\text { Sample } \\
\text { Mean } \\
(\mathbf{M})\end{array}$ & CI 2.5\% & CI 97.5\% \\
\hline Service Quality $\rightarrow$ Attitude & 0.013 & 0.008 & -0.126 & 0.139 \\
\hline Service Quality $\rightarrow$ Intensi & -0.041 & -0.030 & -0.132 & 0.068 \\
\hline Product Choice $\rightarrow$ Attitude & 0.302 & 0.292 & 0.131 & 0.444 \\
\hline Product Choice $\rightarrow$ Intensi & 0.058 & 0.056 & -0.081 & 0.197 \\
\hline Islamic Debt Policy $\rightarrow$ Attitude & 0.037 & 0.039 & -0.093 & 0.168 \\
\hline Islamic Debt Policy $\rightarrow$ Intensi & 0.029 & 0.030 & -0.087 & 0.139 \\
\hline Pricing Policy $\rightarrow$ Attitude & -0.041 & -0.024 & -0.133 & 0.079 \\
\hline Pricing Policy $\rightarrow$ Intensi & 0.023 & 0.027 & -0.056 & 0.106 \\
\hline $\begin{array}{l}\text { Institutional Compliance } \\
\text { on Maqashid } \rightarrow \text { Attitude }\end{array}$ & 0.331 & 0.337 & 0.192 & 0.495 \\
\hline $\begin{array}{l}\text { Institutional Compliance } \\
\text { on Maqashid } \rightarrow \text { Intensi }\end{array}$ & 0.079 & 0.083 & -0.031 & 0.195 \\
\hline Social Influence $\rightarrow$ Attitude & 0.250 & 0.251 & 0.101 & 0.405 \\
\hline Social Influence $\rightarrow$ Intensi & 0.103 & 0.099 & -0.015 & 0.202 \\
\hline Attitude $\rightarrow$ Intensi & 0.714 & 0.710 & 0.587 & 0.824 \\
\hline
\end{tabular}

Gambar 11. Hasil Uji Validitas metode Discriminant Validity dengan pendekatan HTMT inference 


\begin{tabular}{|c|c|c|c|}
\hline Variabel & $\begin{array}{l}\text { Cronbach's } \\
\text { Alpha }\end{array}$ & rho_A & $\begin{array}{l}\text { Composite } \\
\text { Reliability }\end{array}$ \\
\hline Service Quality & 0.865 & 0.913 & 0.919 \\
\hline Product Choice & 0.753 & 0.782 & 0.859 \\
\hline Islamic Debt Policy & 0.866 & 0.905 & 0.916 \\
\hline Pricing Policy & 0.804 & 0.815 & 0.865 \\
\hline $\begin{array}{l}\text { Institutional Compliance on } \\
\text { Maqashid }\end{array}$ & 0.744 & 0.741 & 0.855 \\
\hline Social Influence & 0.860 & 0.862 & 0.899 \\
\hline Attitude & 0.923 & 0.925 & 0.946 \\
\hline Intensi & 0.887 & 0.894 & 0.922 \\
\hline
\end{tabular}

Gambar 13. Hasil Uji Reliabilitas

Gambar 13. Hasil Uji Reliabilitas menunjukkan bahwa hasil pengujian composite reliability menunjukan seluruh nilai variabel laten memiliki nilai cronbach's alpha, rho_A dan composite reliability memenuhi kriteria lolos uji reliabilitas. Dengan demikian semua konstruk dapat diterima reliabilitasnya.

\section{Analisis Hasil Penelitian dan Pembahasan}

Berdasarkan hasil pengujian pada pengaruh service quality terhadap attitude memiliki nilai path coefficients 0.014 yang mendekati nilai +1 , nilai $T$-Statistic 0.196 $(<1.96)$, serta nilai $p$-value $0.844(>0.05)$, sehingga dapat disimpulkan bahwa hipotesis pertama (H1) ditolak dan service quality berpengaruh positif dan tidak signifikan terhadap attitude. Hal tersebut dapat disimpulkan bahwa faktor service quality tidak akan memengaruhi attitude. Hasil penelitian ini sejalan dengan penelitian yang dilakukan oleh (Amin et al., 2017) yang menemukan bahwa service quality berpengaruh positif dan tidak signifikan terhadap attitude konsumen dalam memilih pembiayaan rumah syariah pada konsumen di Malaysia.

Berdasarkan hasil pengujian pada pengaruh product choice terhadap attitude memiliki nilai path coefficients 0.300 yang mendekati nilai +1 , nilai T-Statistic 3.918 (>1.96), serta nilai $p$-value $0.000(<0.05)$, sehingga dapat disimpulkan bahwa hipotesis pertama (H1) diterima dan product choice berpengaruh positif dan signifikan terhadap attitude. Hal tersebut dapat disimpulkan bahwa faktor product choice akan attitude. Hasil penelitian ini sejalan dengan penelitian yang dilakukan oleh (Amin et al., 2017) yang menemukan bahwa product choice berpengaruh positif dan signifikan terhadap attitude konsumen dalam memilih pembiayaan Rumah Syariah pada konsumen di Malaysia.

Berdasarkan hasil pengujian pada pengaruh islamic debt policy terhadap attitude memiliki nilai path coefficients 0.038 yang mendekati nilai +1 , nilai $T$-Statistic 0.612 $(<1.96)$, serta nilai $p$-value $0.541(>0.05)$, sehingga dapat disimpulkan bahwa hipotesis pertama (H1) ditolak dan islamic debt policy berpengaruh positif dan tidak signifikan terhadap attitude. Hal tersebut dapat disimpulkan bahwa faktor islamic debt policy tidak akan memengaruhi attitude. Hasil penelitian ini sejalan dengan penelitian yang dilakukan 
oleh (Amin et al., 2017)yang menemukan bahwa islamic debt policy berpengaruh positif dan tidak signifikan terhadap attitude konsumen dalam memilih pembiayaan Rumah Syariah pada konsumen di Malaysia.

Berdasarkan hasil pengujian pada pengaruh pricing policy terhadap attitude memiliki nilai path coefficients $-0,04$ yang mendekati nilai +1 , nilai $\mathrm{T}$-Statistic 0,724 $(<1.96)$, serta nilai $p$-value $0,469(>0.05)$, sehingga dapat disimpulkan bahwa hipotesis pertama $(\mathrm{H} 1)$ ditolak dan pricing policy berpengaruh negatif dan tidak signifikan terhadap attitude. Hal tersebut dapat disimpulkan bahwa faktor pricing policy tidak akan memengaruhi attitude. Hasil penelitian ini sejalan dengan penelitian yang dilakukan oleh yang menemukan bahwa pricing berpengaruh negatif dan signifikan terhadap attitude dalam menggunakan pembiayaan pribadi Islam.

Berdasarkan hasil pengujian pada pengaruh institutional compliance on maqashid terhadap attitude memiliki nilai path coefficients 0.333 yang mendekati nilai +1 , nilai $T$ Statistic 4.378 (>1.96), serta nilai p-value $0.000(<0.05)$, sehingga dapat disimpulkan bahwa hipotesis pertama (H1) diterima dan institutional compliance on maqashid berpengaruh positif dan signifikan terhadap attitude. Hal tersebut dapat disimpulkan bahwa faktor institutional compliance on maqashid akan memengaruhi attitude. Hasil penelitian ini sejalan dengan penelitian yang dilakukan oleh Amin.,dkk (2019) yang menemukan bahwa institutional compliance on maqashid berpengaruh positif dan signifikan terhadap attitude konsumen dalam memilih pembiayaan Rumah Syariah di Malaysia.

Berdasarkan hasil pengujian pada pengaruh social influence terhadap attitude memiliki nilai path coefficients 0.249 yang mendekati nilai +1 , nilai $T$-Statistic 3.141 (>1.96), serta nilai p-value $0.002(<0.05)$, sehingga dapat disimpulkan bahwa hipotesis pertama (H1) diterima dan social influence berpengaruh positif dan signifikan terhadap attitude. Hal tersebut dapat disimpulkan bahwa faktor social influence akan memengaruhi attitude. Hasil penelitian ini sejalan dengan penelitian yang dilakukan oleh Amin.,dkk (2019) yang menemukan bahwa blog influence berpengaruh positif dan signifikan terhadap attitude konsumen dalam memilih pembiayaan Rumah Syariah di Malaysia.

Berdasarkan hasil pengujian pada pengaruh attitude terhadap intensi memiliki nilai path coefficients 0.856 yang mendekati nilai +1 , nilai T-Statistic 35.581 (>1.96), serta nilai $p$-value $0.000(<0.05)$, sehingga dapat disimpulkan bahwa hipotesis pertama (H1) diterima dan attitude berpengaruh positif dan signifikan terhadap intensi. Hal tersebut dapat disimpulkan bahwa faktor attitude akan mempengaruhi intensi para responden. Hasil penelitian ini sejalan dengan penelitian yang dilakukan oleh Azis., dkk (2018) yang menemukan bahwa attitude berpengaruh positif dan signifikan terhadap intensi konsumen dalam menggunakan Perbankan Syariah di Pakistan.

Berdasarkan hasil analisis model struktural pada penelitian ini, variabel mediasi memiliki nilai $\mathrm{R}$ square sebesar 0,73 . Hal ini dapat diinterpretasikan bahwa variabel Service Quality, Product Choice, Islamic Debt Policy, Pricing Policy, Institutional Compliance on Maqashid, dan Social Influence memiliki pengaruh sebesar 55 \% terhadap attitude, yang dijadikan variabel mediasi alam penelitian ini, sementara sisa $45 \%$ dipengaruhi oleh variabel lain di luar model yang diajukan. 
Hal ini berarti Service Quality, Product Choice, Islamic Debt Policy, Pricing Policy, Institutional Compliance on Maqashid, dan Social Influence dapat mendorong terbentuknya attitude generasi milenial untuk menggunakan KPR di bank syariah dengan tingkat $55 \%$. Kemudian attitude sendiri memiliki pengaruh sebesar $73 \%$ terhadap intensi dan sisa $27 \%$ dipengaruhi oleh variabel lain di luar variabel yang diajukan dalam penelitian ini. Hal ini berarti attitude berperan besar dalam mendorong terbentuknya intensi atau kecenderungan generasi milenial untuk menggunakan KPR di Bank Syariah sebesar $73 \%$.

Menurut (Ayuniah, 2018), apabila hasil pengolahan data diperoleh nilai $R$ square sebesar 0,67, maka hal ini menunjukkan bahwa variabel independent bernilai baik terhadap variabel dependen, sedangkan jika diperoleh nilai $R$ square sebesar 0,33 maka pengaruh variabel independen terhadap variabel dependen bernilai sedang. Kemudian jika nilai $R$ square yang diperoleh adalah 0,19 atau dibawahnya, maka variabel independen memiliki pengaruh yang lemah terhadap variabel dependen. Berdasarkan hal tersebut, dapat disimpulkan bahwa model struktural yang diajukan pada penelitian ini mampu memprediksi dengan baik untuk menilai intensi generasi milenial dalam menggunakan KPR di Bank Syariah.

Berikutnya, berdasarkan hasil analisis path coefficient, variabel Service Quality, Product Choice, Islamic Debt Policy, Institutional Compliance on Maqashid, dan Social Influence memiliki hubungan positif terhadap variabel mediasi attitude. Hal tersebut berarti bahwa adanya perubahan pada kelima variabel ini di generasi milenial akan memiliki pengaruh yang berbanding lurus terhadap perubahan attitude generasi milenial terhadap KPR di bank syariah. Sedangkan hasil analisis path coefficient untuk variabel Pricing Policy bernilai negatif, yang artinya adanya perubahan kebijakan harga di bank syariah belum tentu berbanding lurus dengan Attitude generasi milenial terhadap KPR di bank syariah.

Sedangkan hasil analisis path coefficient variabel Attitude terhadap variabel Intensi memiliki hubungan positif. Hal ini berarti perubahan yang terjadi pada variabel Attitude berbanding lurus dengan Intensi generasi milenial terhadap KPR di bank syariah. Hasil penelitian ini sejalan dengan penelitian terdahulu yang dilakukan oleh (Amin et al., 2017) (Amin, 2020) yang menyatakan bahwa Attitude merupakan variabel mediasi yang memiliki pengaruh signifikan dengan hubungan positif terhadap intensi menggunakan KPR di bank syariah.

Hasil penelitian ini juga menegaskan bahwa Attitude adalah variabel mediasi yang andal (Eles \& Sihombing, 2016). Temuan ini konsisten dengan penelitian terdahulu yang dilakukan oleh yang mengacu pada penelitian yang membuktikan pentingnya Attitude sebagai faktor mediasi dalam penelitian psikologi konsumen. Ini menunjukkan bahwa efek Service Quality, Product Choice, Islamic Debt Policy, Institutional Compliance on Maqashid, dan Social Influence terhadap intensi dapat dimediasi oleh Attitude konsumen. Hal ini juga menunjukkan bahwa Attitude dapat digambarkan sebagai tolok ukur untuk memahami intensi generasi milenial terhadap pembiayaan KPR di bank syariah. Kecenderungan seseorang untuk mengambil produk pembiayaan KPR syariah cenderung lebih besar apabila Attitude konsumen yang terbentuk sudah positif 
dari penelitian ini, diketahui bahwa berkaitan dengan Attitude, pengetahuan konsumen yang cukup akan dapat meningkatkan kepercayaan dan keyakinan untuk cenderung menggunakan produk perbankan syariah. Hal ini meliputi informasi dari sekitar yang tidak hanya berasal dari pihak bank syariah saja, tetapi juga kerabat, keluarga dan lingkungan konsumen. Sehingga, pengambilan keputusan konsumen tidak murni hanya berasal dari dalam dirinya sendiri. Hasil penelitian ini menunjukkan pentingnya bagi bank syariah untuk dapat meningkatkan pelayanan dan pilihan produk agar bisa diterima oleh konsumen dari berbagai target segmen masyarakat. Penting pula bagi bank syariah untuk dapat menekankan bahwa produknya sudah mematuhi prinsip - prinsip syariat islam.

\section{Kesimpulan}

Penelitian ini menemukan bahwa variabel Product Choice, Institutional Compliance on Maqashid, dan Social Influence berpengaruh positif dan signifikan terhadap Attitude generasi milenial dalam hal pembiayaan kepemilikan rumah di bank syariah. Kemudian variabel Service Quality dan Islamic Debt Policy tidak berpengaruh signifikan terhadap Attitude, sedangkan variabel Pricing Policy berpengaruh negatif dan tidak signifikan terhadap Attitude generasi milenial dalam hal pembiayaan kepemilikan rumah di bank syariah.

Hasil penelitian yang dilakukan dengan menggunakan Theory Reasoned Action (TRA) sebagai landasan utama dengan menggunakan variabel independen Service Quality, Product Choice, Islamic Debt Policy, Pricing Policy, Institutional Compliance on Maqashid, dan Social Influence menunjukkan bahwa variabel sikap (Attitude) dapat memediasi intensi generasi milenial dalam memilih produk pembiayaan kepemilikan rumah melalui bank syariah.

Temuan dalam penelitian ini menunjukkan pula bahwa tanpa adanya Attitude, intensi akan sulit diamati. Hal ini karena Attitude memegang peran sebesar $73 \%$ terhadap kecenderungan atau intensi generasi milenial terhadap produk pembiayaan rumah di bank syariah.

\section{Bibliografi}

Amin, H. (2020). Examining the influence of factors critical for the consumer to accept the offered Islamic home financing. Journal of Islamic Accounting and Business Research, 11(7), 1379-1402. https://doi.org/10.1108/JIABR-07-2018-0110.

Ayuniah, Putri. (2018). Analisis Pengaruh Citra Merek, Kualitas Produk, Iklan, dan Harga terhadap Keputusan Pembelian Produk Kosmetik Wardah (Studi Kasus pada Mahasiswi Jurusan Manajemen Fakultas Ekonomi Universitas Gunadarma yang Mengambil Kuliah di Kampus Depok). Jurnal Ilmiah Ekonomi Bisnis, 22(3).

Brant, K., \& Castro, S. (2019). You can't ignore millennials: Needed changes and a new way forward in entitlement research. You Can't Ignore Millennials: Needed Changes and a New Way Forward in Entitlement Research.

Christopher Kurz, Geng Li, and D. J. V. (2018). Finance and Economics Discussion Series Divisions of Research \& Statistics and Monetary Affairs Federal Reserve Board, Washington, D . C . Credit Derivatives and Risk Management. Finance and Economics, 32(3), 20. http://papers.ssrn.com/sol3/papers.cfm?abstract_id=1750286

Dickerson, A. M. (2016). Millennials, Affordable Housing, and the Future of 
Homeownership. Journal of Affordable Housing, 24(3), 435-465.

Eles, Shella F., \& Sihombing, Sabrina O. (2016). Determinan niat beli makanan organik: sikap untuk membeli sebagai variabel mediasi. MIX: Jurnal Ilmiah Manajemen, 6(3), 156574.

Ghozali, I. (2016). Aplikasi Analisis Multivariate Dengan Program IBM SPSS 2.

Henseler, J., Ringle, C. M., \& Sarstedt, M. (2015). A new criterion for assessing discriminant validity in variance-based structural equation modeling. Journal of the Academy of Marketing Science, 43(1), 115-135. https://doi.org/10.1007/s11747014-0403-8

Hoolachan, J., \& McKee, K. (2019). Inter-generational housing inequalities: 'Baby Boomers' versus the 'Millennials.' Urban Studies, 56(1), 210-225. https://doi.org/10.1177/0042098018775363

Ismail, S., Azmi, F., \& Thurasamy, R. (2014). Selection criteria for Islamic home financing in Malaysia. International Journal of Business and Society, 15(1), 97110.

Larasati, Niken Febria. (2019). Analisis Perilaku Generasi Milenial Terhadap Niat Menjadi Nasabah Bank Syariah. Jakarta: Fakultas ekonomi dan bisnis uin jakarta.

Mirza Astia Amri. (2018). Faktor-Faktor Yang Mempengaruhi Keputusanan Nasabah Bank OCBC NISP Medan Dalam Pemilihan KPR Konvensional Dan Syariah. 1369.

Sugiyono. (2012). Metode Penelitian Administrasi Dilengkapi dengan Metode R\&D.

Widjieanto, Garant Fortino. (2020). Analisa Pengaruh User Experience Terhadap Customer Loyalty Dengan Trust Sebagai Variabel Intervening Pada Aplikasi Digital Payment Dana. Jurnal Strategi Pemasaran, 7(1), 9.

Wong, K. K. (2019). Mastering Partial Least Squares Structural Equation Modeling (PLS-SEM) with SmartPLS in 38 Hours.

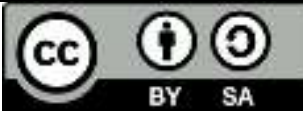

This work is licensed under a Creative Commons Attribution-ShareAlike 4.0 International License. 